\title{
THE PRODUCTIVITY OF SOME MONOECIOUS HEMP VARIETIES (FOR FIBER AND MIXTE) UNDER THE CENTER OF MOLDAVIA ECOPEDOCLIMATIC CONDITIONS
}

\author{
ALEXANDRA - ANDREEA BUBURUZ ${ }^{*}$, LORENA - DIANA POPA $^{1}$ \\ ${ }^{1}$ Agricultural Research - Development Station Secuieni, Principala Street, no. 377, \\ Secuieni, Neamt county, 617415, Romania
}

\begin{abstract}
The present paper presents the results obtained regarding the evolution of stem and fiber production in monoecious hemp, under the pedoclimatic conditions of the Center of Moldova, between 2012 and 2016. The biological material used was represented by four monoecious hemp varieties created at S.C.D.A. Secuieni, respectively, Denise, Diana, Dacia - Secuieni and Ratza. The stems yields achieved, have varied widely, ranging from 7860 $\mathrm{kg} / \mathrm{ha}$ at Denise variety, in 2016 (a very warm agricultural year from the thermal point of view and rainy from the pluviometric point of view), and $15167 \mathrm{~kg} / \mathrm{ha}$, at Dacia - Secuieni in 2014 (a normal agricultural year both from the thermal and pluviometric point of view). On average, during the five years studied, the highest production of fiber was obtained in the Dacia-Secuieni variety in 2014 , of $5005 \mathrm{~kg} / \mathrm{ha}$, and the lowest of $2279 \mathrm{~kg} / \mathrm{ha}$ at Denise variety in 2016.
\end{abstract}

Keywords: monoecious hemp, yield, stems, fiber

\section{INTRODUCTION}

Cultivated and used for various purposes since $10,000 \mathrm{BC}$, considered to be the plant with more than 50000 uses, hemp focuses its attention, and today, on the importance and wide variety of its uses.

Hemp can be grown for seeds, fiber or mixed purpose in different geographic and climatic areas $[1,2,3,4,5]$ being an idustrial plant with sustainable yield, that can help meet the increasing demand for fiber worldwide.

The stems wood fibers, can be used for everything from jewelery, animal bedding, plastics to clothing $[6,7,8,9$, 10]. Hemp fiber can replace glass fiber in some automotive and aviation components, and can also be a perfect substitute for insulated glass fiber.

By presenting high yields of fiber and strains per hectare, with their valuable features, hemp will be a plant of high importance also in the future.

\section{EXPERIMENTAL SETUP}

The researches were carried out between 2012 - 2016, at S.C.D.A. Secuieni and aimed to establish the most productive monoecious hemp variety under the ecopedoclimatic conditions from Center of Moldova.

\footnotetext{
* Corresponding author, email: alexandra.buburuz@scda.ro

(C) 2017 Alma Mater Publishing House
} 
Placement of the experience was done by the randomized block method in three repetitions. The experimental plot had a collectable surface of 10 square meters.

The settlement was carried out in the experimental field of the unit on a medium - textured typical faeoziom (chernozem) cambic soil, characterized as medium supplied in active humus $(1.88 \%)$ and nitrogen $(16.2 \mathrm{ppm} \mathrm{N}$ NO3), well supplied in phosphorus (77.6 ppm PAL), Ca (13, $6 \mathrm{meq} / 100 \mathrm{~g}$ sol Ca) and $\mathrm{Mg}(1.8 \mathrm{meq} / 100 \mathrm{~g}$ soil $\mathrm{Mg}$ ), poorly supplied in potassium $\left(124.6 \mathrm{ppm} \mathrm{K}_{2} \mathrm{O}\right)$ and slightly acidic, with a water $\mathrm{pH}$ of 5.98 .

Experimentation was conducted under non-irrigated conditions, and in each year of the analyzed period, the crop was fertilized with $110 \mathrm{~kg} / \mathrm{ha}$ a.s. N, $40 \mathrm{~kg} / \mathrm{ha} \mathrm{P}_{2} \mathrm{O}_{5}$ and $40 \mathrm{~kg} / \mathrm{ha} \mathrm{K}_{2} \mathrm{O}_{5}$, and herbicide with $1.0 \mathrm{~L} / \mathrm{ha}$ Fusilade and $0.5 \mathrm{~L} / \mathrm{ha}$ Lontrel. The sowing was carried out at the optimum time for this area.

The cultivation technology specific to the ecopedoclimatic conditions in the Center of Moldova was respected and the data obtained were processed and statistically interpreted by the variance analysis method [10].

For the entire growing season of hemp crop (from sowing to physiological maturity), the deviation from the multiannual average temperature varied between $0.4{ }^{\circ} \mathrm{C}(2014)$ and $3.3{ }^{\circ} \mathrm{C}(2016)$.

From the temperatures point of view, the monoecious hemp vegetation period of the experimental year compared to the multiannual average was characterized as normal $(2013,2014)$, warm $(2015)$ and very warm $(2012,2016)$ (Table 1).

Table 1. Temperatures recorded at S.C.D.A. Secuieni meteorological station.

\begin{tabular}{|c|c|c|c|c|c|c|c|c|c|c|c|c|}
\hline \multirow{2}{*}{$\begin{array}{l}\text { Average } \\
\text { temperature } \\
{ }^{\circ} \mathbf{C}\end{array}$} & \multicolumn{9}{|c|}{ Months } & \multirow{2}{*}{$\begin{array}{c}\text { Average } \\
\text { per } \\
\text { vegetation } \\
\text { period }\end{array}$} & \multirow{2}{*}{ Deviation } & \multirow{2}{*}{$\begin{array}{c}\text { Vegetation } \\
\text { period } \\
\text { charact. }\end{array}$} \\
\hline & Jan. & Febr. & Mar & Apr & Mai & Jun. & Jul. & Aug & Sept & & & \\
\hline 2012 & -3.4 & -10.7 & 2.2 & 11.7 & 16.8 & 21.1 & 23.5 & 21.3 & 17.7 & 18.7 & 2.3 & Very warm \\
\hline 2013 & -5.0 & -1.1 & 0.8 & 11.5 & 17.7 & 19.9 & 20.5 & 20.4 & 14.2 & 17.4 & 1.0 & norm. \\
\hline 2014 & -2.6 & -1.7 & 7.1 & 10.0 & 15.5 & 18.2 & 20.8 & 20.6 & 15.8 & 16.8 & 0.4 & norm. \\
\hline 2015 & -1.6 & -0.2 & 4.5 & 9.5 & 16.6 & 20.1 & 22.8 & 22.4 & 18.4 & 18.3 & 1.9 & warm \\
\hline 2016 & -3.0 & 4.2 & 5.7 & 13.5 & 14.9 & 20.3 & 31.7 & 20.6 & 17.3 & 19.7 & 3.3 & Very warm \\
\hline $\begin{array}{l}\text { Multiannua } \\
\text { l average }\end{array}$ & -3.8 & -2.3 & 2.6 & 9.4 & 15,4 & 18.8 & 20.3 & 19.5 & 14.9 & 16.4 & - & - \\
\hline
\end{tabular}

In terms of rainfall, the deviation from the precipitation multiannual average ranged between $-233.3 \mathrm{~mm}$ (2015) and $21.1 \mathrm{~mm}$ (2016), and was characterized as normal in 2013 and 2014, drought in 2012, very drought in 2015 and very rainy in 2016 (Table 2).

Table 2. Rainfall recorded at S.C.D.A. Secuieni meteorological station.

\begin{tabular}{|c|c|c|c|c|c|c|c|c|c|c|c|c|}
\hline \multirow{2}{*}{$\begin{array}{l}\text { Rainfall } \\
(\mathrm{mm})\end{array}$} & \multicolumn{9}{|c|}{ Months } & \multirow{2}{*}{$\begin{array}{l}\text { Suma } \\
\text { pe per. } \\
\text { de veg. }\end{array}$} & \multirow[t]{2}{*}{ Deviation } & \multirow{2}{*}{$\begin{array}{c}\text { Vegetation } \\
\text { period } \\
\text { charact. }\end{array}$} \\
\hline & Jan. & Febr. & Mar & Apr. & May & Jun. & July & Aug & Sept & & & \\
\hline 2012 & 11.0 & 12.0 & 28.2 & 68.0 & 93.6 & 53.8 & 19.0 & 26.4 & 24.0 & 284.8 & -101.9 & drought \\
\hline 2013 & 14.2 & 28.8 & 33.4 & 38.2 & 51.4 & 146.0 & 76.4 & 42.0 & 42.6 & 396.6 & 9.9 & norm. \\
\hline 2014 & 22.6 & 6.8 & 26.4 & 77.8 & 96.2 & 66.6 & 91.1 & 37.0 & 9.2 & 377.9 & $-8 ., 8$ & norm. \\
\hline 2015 & 8.8 & 16.0 & 43.4 & 25.4 & 5.6 & 34.0 & 51.0 & 12.6 & 24.8 & 153.4 & -233.3 & $\begin{array}{c}\text { Very } \\
\text { drought }\end{array}$ \\
\hline 2016 & 12.0 & 14.2 & 29.4 & 42.0 & 120.2 & 161.0 & 4.0 & 32.0 & 48.6 & 407.8 & 21.1 & Very rainy \\
\hline $\begin{array}{l}\text { Multiannua } \\
\text { l average }\end{array}$ & 20.5 & 19.6 & 25.4 & 46.8 & 64.8 & 84.3 & 84.0 & 61.4 & 45.4 & 386.7 & - & - \\
\hline
\end{tabular}




\section{RESULTS AND DISCUSSION}

In 2012, the strain yields of the experienced varieties ranged between $8753 \mathrm{~kg} / \mathrm{ha}$ (Denise) and $13300 \mathrm{~kg} / \mathrm{ha}$ (Dacia - Secuieni). Production increases at strains, statistically ensured as very significantly, were obtained in Dacia - Secuieni $(2201 \mathrm{~kg} / \mathrm{ha})$ and Ratza $(2132 \mathrm{~kg} / \mathrm{ha})$ varieties, while Denise and Diana varieties have obtained production minuses $(-2345 \mathrm{~kg} / \mathrm{ha},-1991 \mathrm{~kg} / \mathrm{ha})$ which were statistically insured and recorded as very significant negative compared to the experience average (control) (Table 3).

The yields obtained in 2013 agricultural year were between $10700 \mathrm{~kg} / \mathrm{ha}$ (Denise) and $15132 \mathrm{~kg} / \mathrm{ha}$ (Dacia Secuieni). Compared with the experience average, two varieties achieved very significant production increases (Dacia - Secuieni and Ratza) and two varieties achieved very significant negative production increases (Table $3)$.

In the third year of experimentation (2014), the varieties yields ranged from $10660 \mathrm{~kg} / \mathrm{ha}$ at Denise variety to $15167 \mathrm{~kg} / \mathrm{ha}$ at Dacia - Secuieni variety. Compared with the experience average, Dacia - Secuieni (2614 kg/ha) and Ratza $(774 \mathrm{~kg} / \mathrm{ha})$ achieved very significant production increases, while the Denise and Diana varieties obtained production minuses (-1893 kg/ha, $-1497 \mathrm{~kg} / \mathrm{ha}$ ) interpreted as negative very significant (Table 3 ).

In 2015 agricultural year, superior yields were obtained at Dacia - Secuieni (13512 kg/ha) and Ratza (13200 $\mathrm{kg} / \mathrm{ha}$ ) varieties, the production increases being statistically interpreted as very significant, at Dacia - Secuieni $(2346 \mathrm{~kg} / \mathrm{ha})$ and Ratza (2034 kg/ha) compared to the experience average (Table 3$)$.

In the last year of experimentation (2016), the varieties yields ranged widely between $7860 \mathrm{~kg} / \mathrm{ha}$ (Denise) and $14200 \mathrm{~kg} / \mathrm{ha}$ (Dacia - Secuieni). Compared with the experience average, the Dacia - Secuieni (3017 kg/ha) and Ratza $(2719 \mathrm{~kg} / \mathrm{ha})$ varieties have obtained very significant production increases, while the Denise and Diana varieties obtained production minuses $(-3323 \mathrm{~kg} / \mathrm{ha},-2413 \mathrm{~kg} / \mathrm{ha}$ ) interpreted as negative very significant (Table $3)$.

On average, during the five years of experimentation, the yields of the studied varieties ranged from $9362 \mathrm{~kg} / \mathrm{ha}$ at Denise variety up to $14262 \mathrm{~kg} / \mathrm{ha}$ at Dacia - Secuieni variety. Production increases at strains, statistically ensured as very significantly, were obtained at Dacia - Secuieni (2498 kg/ha) and Ratza (1832 kg/ha) varieties, while the Denise and Diana varieties obtained production minuses $(-2402 \mathrm{~kg} / \mathrm{ha},-1934 \mathrm{~kg} / \mathrm{ha})$ which were statistically insured and interpreted as very significant negative compared to the experience average (control) (Table 3).

Regarding the fiber yields obtained at the experienced varieties in 2012 they were between $2538 \mathrm{~kg} / \mathrm{ha}$ (Denise) and $4389 \mathrm{~kg} / \mathrm{ha}$ (Dacia - Secuieni). Production increases at fiber, statistically ensured as very significantly, were obtained in Dacia - Secuieni $(893 \mathrm{~kg} / \mathrm{ha})$ and Ratza $(738 \mathrm{~kg} / \mathrm{ha})$, while the Denise and Diana varieties obtained production minuses $(-958 \mathrm{~kg} / \mathrm{ha},-673 \mathrm{~kg} / \mathrm{ha}$ ) that were statistically insured and recorded as very significant negative compared to the experience average (control) (Table 4).

The yields obtained in 2013 agricultural year had values ranging from $3103 \mathrm{~kg} / \mathrm{ha}$ (Denise) and $4994 \mathrm{~kg} / \mathrm{ha}$ (Dacia - Secuieni). Compared with the experience average, two varieties achieved very significant production increases (Dacia - Secuieni and Ratza) and two varieties achieved very significant negative production increases (Table 4).

In the third year of experimentation (2014), the varieties yields ranged from $3091 \mathrm{~kg} / \mathrm{ha}$ at Denise variety to $5005 \mathrm{~kg} / \mathrm{ha}$ at Dacia - Secuieni variety. In comparison to the experience average, Dacia - Secuieni (1058 kg/ha) and Ratza ( $318 \mathrm{~kg} / \mathrm{ha}$ ) have obtained very significant production increases, while the Denise and Diana varieties obtained production minuses $(-856 \mathrm{~kg} / \mathrm{ha},-520 \mathrm{~kg} / \mathrm{ha}$ ) interpreted as negative very significant (Table 4$)$.

In 2015 agricultural year, superior yields were obtained at Dacia - Secuieni (4459 kg/ha), Ratza (4224 kg/ha) and Diana $(2826 \mathrm{~kg} / \mathrm{ha})$ varieties, the production increases being statistically interpreted as very significant, at Dacia - Secuieni (941 kg/ha) and Ratza (706 kg/ha) varieties compared to the experience average (Table 4). 


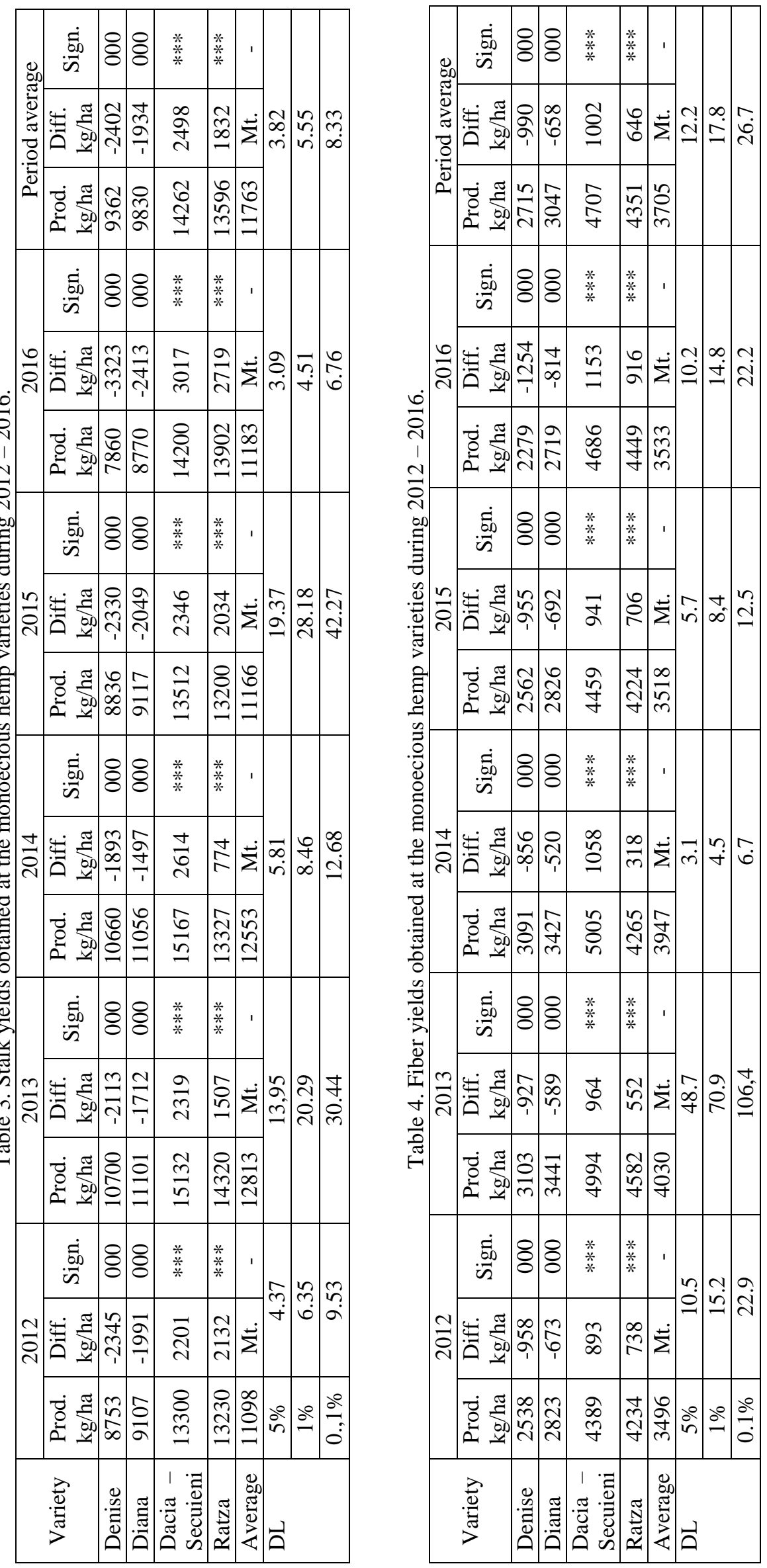


In the last year of experimentation (2016), the varieties yields ranged widely between $2279 \mathrm{~kg} / \mathrm{ha}$ (Denise) and $4686 \mathrm{~kg} / \mathrm{ha}$ (Dacia - Secuieni). Of the 4 studied varieties, compared with the experience average, Dacia Secuieni (1153 kg/ha) and Ratza (916 kg/ha) have achieved very significant production increases, while the Denise and Diana varieties obtained production minuses $(-1254 \mathrm{~kg} / \mathrm{ha},-814 \mathrm{~kg} / \mathrm{ha})$ interpreted as a very significant negative (Table 4).

On average, during the experimentation period, the yields of the studied varieties ranged from $2715 \mathrm{~kg} / \mathrm{ha}$ at Denise variety and up to $4707 \mathrm{~kg} / \mathrm{ha}$ at Dacia - Secuieni variety. Production increases at fiber, statistically insured as very significant, were obtained at Dacia - Secuieni $(1002 \mathrm{~kg} / \mathrm{ha})$ and Ratza $(646 \mathrm{~kg} / \mathrm{ha}) \mathrm{varieties}$, while the Denise and Diana varieties obtained production minuses $(-990 \mathrm{~kg} / \mathrm{ha},-658 \mathrm{~kg} / \mathrm{ha})$ which were statistically insured and interpreted as very significant negative compared to the experience average (control) (Table 4).

\section{CONCLUSIONS}

The average production of strains of the four varieties experienced at S.C.D.A. Secuieni was between $9362 \mathrm{~kg} / \mathrm{ha}$ at Denise and $14262 \mathrm{~kg} / \mathrm{ha}$ at Dacia - Secuieni.

On average, during the five years of experimentation, compared to the experience average (control), two varieties (Dacia - Secuieni and Ratza) have obtained production increases (2498 kg/ha, $1832 \mathrm{~kg} / \mathrm{ha})$ statistically ensured as very significant, while the other two varieties (Denise and Diana) have obtained production minuses $(-2402 \mathrm{~kg} / \mathrm{ha},-1934 \mathrm{~kg} / \mathrm{ha})$ which were statistically insured and interpreted as negative very significant.

The average fiber production of the four varieties experienced at S.C.D.A. Secuieni was between $2715 \mathrm{~kg} / \mathrm{ha}$ at Denise and $4707 \mathrm{~kg} / \mathrm{ha}$ at Dacia - Secuieni.

During 2012 - 2016, compared to the experience average (control), two varieties (Dacia - Secuieni and Ratza) have achieved production increases $(1002 \mathrm{~kg} / \mathrm{ha}, 646 \mathrm{~kg} / \mathrm{ha})$ statistically ensured as very significant, while the other two varieties (Denise and Diana) have obtained production minuses (-990 kg/ha, $-658 \mathrm{~kg} / \mathrm{ha}$ ) which were statistically insured and interpreted as negative very significant.

\section{REFERENCES}

[1] Van der Werf, H.M.G., Wijlhuizen, M., De Schutter, J.A.A., Plant density and self-thinning affect yield and quality of fibre hemp (Cannabis sativa L.), Field crops research, vol. 40, no. 3, 1995, p. 153-164.

[2] Lisson, S.N., Mendham, N.J., Cultivar, sowing date and plant density studies of fibre hemp (Cannabis sativa

L.) in Tasmania, Australian journal of experimental agriculture, vol. 40, no. 7, 2000, p. 975 - 986.

[3] Salentijn, E.M.J., Zhang, Q., Amaducci, S., Yang, M., Trindade, L.M., New developments in fiber hemp (Cannabis sativa L.) breeding, Industrial crops and products. 2014. doi: 10.1016/j.indcrop.2014.08.011.

[4] Salentijn Elma, M.J., Zhang, Q., Amaducci, S., Yang, M., Trindade, L.M., New developments in fiber hemp (Cannabis sativa L.) breeding, Industrial crops and products, vol. 68, 2015, p. 32-41.

[5] Popa, L.D., A Buburuz, A.A., Isticioaia, S.F., Leonte, A., The seed norms influence on the productivity of some monoecious hemp varieties (for fiber and mixed), under the ecopedoclimatic conditions of A.R.D.S. Secuieni, Agricultural research development station Secuieni Neamt $(1962$ - 2017) - 55 years of research develop, anniversary volume, Ed. Ion Ionescu de la Brad, Iasi, 2017, p. 209 - 216.

[6] Del Gatto, A., Laureti, D., Crescentini, P., Prime valutazioni di cultivar di canapa (Cannabis sativa L.), in ambienti marchigiano - Riv. di Sem. El., 5, 1999, p. 23 - 27;

[7] Hanks, A., Challenges and opportunities: For Canadian hemp fiber. Canadian textile journal, vol. 118, 2001, p. $27-30$.

[8] Crosky, A., Hemp scores highly as reinforcement, Advanced composites bulletin, no. 10, 2001, p. 1 - 3.

[9] Zhou, X., Long, L., Hemp shining with new technology, China textile and apparel, vol. 29, no. 4, 2011 , p. $106-108$.

[10] Ceapoiu, N., Statistical methods applied in agricultural and biological experiments. Ed. Agro - Silvica, Bucharest, 1968. 